\title{
Nitrogen and phosphorus influence Acacia saligna invasiveness in the fynbos biome
}

\author{
Nanike Esterhuizen • Jane Forrester • Karen J. Esler • Corlie Wigley-Coetzee • \\ Rafael Jorge Morcillo • Aleysia Kleinert • María Pérez-Fernández • • \\ Alex J. Valentine
}

Received: 17 July 2019/Accepted: 7 February 2020

(C) Springer Nature B.V. 2020

\begin{abstract}
This study attempts to understand how invasive legumes such as Acacia saligna may compete with indigenous legumes such as Virgilia divaricata. The two species are trees with similar growth forms. We studied the competitive ability of invasive and indigenous seedlings under variations in soil phosphorus availability. South African fynbos vegetation is threatened by invasive Acacia. The indigenous tree legume, Virgilia, grows in similar phosphorus soil conditions as Acacia although there is a gap in the knowledge of their physiology. We investigated the utilization of different inorganic $\mathrm{P}$ sources by the invasive A. saligna and the native $V$. divaricata in the presence and absence of root nodules in each species. Plant performance in terms of photosynthesis and biomass production was also analysed. Plants were
\end{abstract}

Communicated by Michael John Lawes.

N. Esterhuizen · K. J. Esler

Department of Conservation Ecology and Entomology \& Centre for Invasion Biology, Faculty of AgriSciences,

Stellenbosch University, Private Bag X1, Matieland 7602, South Africa

N. Esterhuizen - A. Kleinert - A. J. Valentine

Department of Botany and Zoology, Faculty of Science, Stellenbosch University, Private Bag X1, Matieland 7602, South Africa

J. Forrester

Harold Porter Botanical Garden,

P.O. Box 35, Betty's Bay 7141, South Africa cultivated in silica sand supplied with Long Ashton nutrient solution, modified to contain either $50 \mu \mathrm{M} \mathrm{P}$ or $500 \mu \mathrm{M} \mathrm{P}$ applied as $\mathrm{NaH}_{2} \mathrm{PO}_{4} \cdot 2 \mathrm{H}_{2} \mathrm{O}$. Rate of growth was estimated as the increase in mass in plants harvested after 4 and 8 weeks of growth. After 4 weeks of growth, the seedlings of Virgilia grew quicker and produced more biomass than Acacia, under both phosphorus conditions. However, this was reversed after 8 weeks of growth, with Acacia out-competing Virgilia. Increased growth of the invasive legumes was achieved by relying on soil nitrogen under high phosphorus conditions and shifting to atmospheric sources under lower phosphorus levels. The strategies of altering photosynthetic carbon balance and nitrogen acquisition under varying soil phosphorus conditions potentially underpin the invasive potential of Acacia in fynbos soils.

\author{
C. Wigley-Coetzee \\ South African National Parks, 643 Leyds Street, \\ Muckleneuk, Pretoria, South Africa \\ R. J. Morcillo \\ Shanghai Center for Plant Stress Biology, Chinese \\ Academy of Sciences, No. 3888 Chenhua Road, \\ Shanghai 201602, People's Republic of China \\ M. Pérez-Fernández $(\square)$ \\ Ecology Area, University Pablo de Olavide, Carretera de \\ Utrera Km 1, 41013 Sevilla, Spain \\ e-mail: maperfer@upo.es
}


Keywords Mineral nutrition - Invasive legume · Acacia $\cdot$ Virgilia $\cdot$ Fynbos biome

\section{Introduction}

The fynbos biome is a Mediterranean ecogeographic region located within the Cape Floristic Region (CFR) of South Africa. This biome is well known for its high richness in plant species of which over $70 \%$ are endemic to the CFR (Holmes and Cowling 1997; Myers et al. 2000; Goldblatt and Manning 2002; Rebelo et al. 2006). Fynbos vegetation comprises mainly of slow-growing, fine-leaved, sclerophyllous shrubs, which have adapted to survive in the highly weathered, nutrient-impoverished soils that characterize the region (Read and Mitchell 1983; Goldblatt 1997). The unique biodiversity of the fynbos biome, however, is under great threat from invasion by trees and shrubs of the genera Acacia, Hakea and Pinus (Richardson and Van Wilgen 2004; Lowe et al. 2008; Wilson et al. 2014). These invasive plants have become locally dominant and in some areas have completely replaced the once diverse and indigenous plant communities (Levine et al. 2003). The consequence of this is that stands of invasive alien trees take up $1.6 \%$ of the total vegetation area when condensed (Cowling et al. 2003) and at least 54\% of riparian fynbos has an invasion density of $25 \%$ or more (Thuiller et al. 2005).

Alien Acacia (including A. cyclops, A. saligna, A. longifolia, A. mearnsii and A. melanoxylon) in South Africa have currently replaced much of the critically endangered lowland coastal fynbos due to their invasive capabilities coupled with a lack of capacity to prevent their spread (Richardson 2001; Le Roux et al. 2016). Such invasive species have detrimental effects on indigenous species, community dynamics and the overall function and structure of native ecosystems (Richardson and Van Wilgen 2004; Blackburn et al. 2011; Ndzwanana et al. 2019). Invasive alien plants also reduce the water delivery from catchment areas, with woody species reducing river runoff from $30 \%$ to more than $50 \%$ (Kirkwood et al. 2014).

Although invasive Acacia have increased competitive ability compared to indigenous fynbos vegetation, the exact mechanisms that confer a competitive edge are still unclear. In general, exotic plants may have multitude ways to become successful in their new habitat (Witkowski 1991). Several hypotheses have been proposed to explain the increasing success of invasive species; these include the "enemy release hypothesis" (ERH) which attributes success to the fact that exotics are liberated from natural pathogens and specialist herbivores when introduced into a new habitat (Wolfe 2002; Mitchell and Power 2003; Reinhardt and Callaway 2003; Callaway and Walker 1997; Jacobs et al. 2014). Alien plants can also use 'novel weapons' to decrease growth of other plants. These may include altering the way that nutrients are cycled (Vitousek 1990; Yelenik et al. 2004) or using allelopathic or antimicrobial root exudates ("allelopathic advantage against resident species" or AARS, Callaway and Ridenour 2004). Aliens may also grow better by increasing nutrient acquisition. Compared with the native species they share their environment with, invasive Acacia have been found to (1) adapt root structure (e.g. increase biomass belowground), (2) increase nutrient availability by using root exudates, cluster roots and increasing transpirational water use, and (3) form specialized associations that will increase nutrient uptake e.g. associations with mycorrhizas and $\mathrm{N}$-fixing bacteria (see review by Morris et al. 2011). The latter mechanism is characteristic of leguminous species as they establish symbiotic interactions with rhizobia in the soil. The positive tripartite mycorrhiza-legume-rhizobia relationship is known to confer advantages to the infected plant that can fix atmospheric nitrogen and also can better cope with phosphorus $(\mathrm{P})$ deficiencies in the soil (Richardson et al. 2000; Mortimer et al. 2008; PérezFernández and Lamont 2016). This is particularly true for invasive Acacia, as shown in several studies, where the infection of A. sophorae (Costelo 2000), A. saligna and A. stenophylla (Hoque et al. 2010) or A. dealbata (Lorenzo et al. 2010) by rhizobial partners confer advantages to the plant when using the same resources.

Of all physiological and morphological plant adaptations, the rapid and substantial allocation to root mass and above all the strong biological nitrogen fixation (BNF) abilities of Acacia have been reported to be responsible for their successful invasion (Costelo 2000; Hoque et al. 2010; Morris et al. 2011). Nitrogen $(\mathrm{N})$ is a crucial nutrient for all green plants, but has to be reduced to $\mathrm{NH}_{4}{ }^{+}$to build the chemicals required for growth and reproduction before it can be readily 
utilized by plants (Davidson and Davidson 1993). This process of BNF can only be accomplished through a symbiotic relationship between the plant and specialized bacteria that lives in nodules on the roots of the plant. The extra $\mathrm{N}$ added to the fynbos soils from BNF by invasive alien legumes is problematic for indigenous fynbos plants that are adapted to low-nutrient conditions and now have to face increased concentrations of $\mathrm{N}$ in the soils they share with invasive $\mathrm{N}$ fixers. The contribution of BNF from invasive species is usually much higher than the expected BNF from indigenous nitrogen fixers of a specific region, due to overall faster growth rates resulting from less competition and the lack of natural enemies (Blackburn et al. 2011). Acacia species, in particular, are known to significantly raise levels of soil $\mathrm{N}$ (Yelenik et al. 2004). This reduces the competitiveness of lownutrient adapted fynbos species and furthermore opens the door for further invasion by weedy grass species (Witkowski 1991; Kirkwood et al. 2014).

The restoration of areas previously invaded by Acacia species is problematic because indigenous fynbos vegetation struggle to recolonize under elevated N conditions (Witkowski 1991). It has been suggested before that these areas may be more successfully restored with a native species that can potentially compete with Acacia and have the same functional role with regards to being a pioneer trees species with similar BNF abilities that will not be disadvantaged by the higher nutrient legacy left by Acacia (Coetsee and Wigley 2013). Native woody legumes have been used successfully elsewhere in Mediterranean systems to restore water-deficient, lownutrient environments (Aronson et al. 1993; Herrera et al. 2011; Pérez-Fernández et al. 2016). The legume family, Fabaceae, is the fourth largest plant family in the CFR with 38 genera of which eight are endemic to the region (Goldblatt 1997). This BNF by indigenous Fabaceae is an essential component in natural and in managed ecosystems (Pereira and Bliss 1987; Corbin and D'Antonio 2004) as it maintains a balanced amount of $\mathrm{N}$ in the fynbos soils that is the right for plant growth and maintenance. An example of a woody indigenous legume species that occurs in the CFR and fynbos biome is Virgilia divaricata, the Keurboom. Virgilia species are light-demanding, ecologically important pioneer species that grow abundantly on heavily disturbed forest sites and along riparian zones (Campbell and Moll 1977; Vosse 2007).

After N, P is the second most limiting plant nutrient (Vance et al. 2000). Even though P occurs copiously in several soils, it is not readily available for plant uptake due to the formation of undissolvable compounds with cations (Blackburn et al. 2011; Ragothama 1999; Vance 2001). Moreover, it has widely been found that such $\mathrm{P}$ deficiencies noticeably hamper plant growth as well as BNF in various legume plants (Bethlenfalvay and Philip 1977; Israel 1987; Witkowski 1991; Oliviera et al. 2004; Le Roux et al. 2008; Power et al. 2010). With $P$ being an essential element for $\mathrm{BNF}$, affecting this process of legumes as well as cellular bioenergetics at various levels (Bucher 2006; Maistry et al. 2013), a P deficiency as found in many fynbos soils may regulate the BNF ability of both invasive Acacia as well as indigenous Virgilia species.

Various fynbos plant species have been outcompeted by exotic Acacia because of their inability to fix $\mathrm{N}$ and their lower growth rates under high $\mathrm{N}$ conditions (Witkowski 1991). The study at hand attempts to understand how invasive legumes such as A. saligna may compete with indigenous legumes such as $V$. divaricata, in adapting to $\mathrm{P}$ deficient soils of the fynbos biome. This research defines the physiological mechanisms used by invasive and indigenous legumes to potentially compete in the P-poor soils of the fynbos in their seedling phases.

\section{Methods and materials}

Plant growth conditions

All plants used in this study were grown from February to June in a north-facing glasshouse at Stellenbosch University in the Western Cape, South Africa. Virgilia divaricata seeds were obtained from Kirstenbosch National Botanical Garden in Cape Town, Western Cape, South Africa, and A. saligna seeds were collected from a population near Malmesbury in the Western Cape, South Africa (33.464313, 18.739371). To stimulate germination, seeds from both species were separately treated with Kirstenbosch Instant Smoke Plus Seed Primer (Kirstenbosch National Botanical Garden in Cape Town, Western Cape, South Africa) following the manufacturer instructions. One primer paper disc was 
added to $50 \mathrm{ml}$ of water per container, in which 100 of each species' seeds were soaked for $24 \mathrm{~h}$ in separate containers before sowing. Acacia and Virgilia seeds were separately sown in lowland fynbos soil, collected from the Jan Marais Nature Reserve in Stellenbosch, Western Cape, South Africa (- 33.932429, 18.876057) and allowed to nodulate for 4 weeks, in the indigenous soil. During this period, plants were watered with $100 \mathrm{ml}$ of distilled $\mathrm{H}_{2} \mathrm{O}$ every 3 days. The daily temperatures in the glasshouse for the duration of the experiments were as follows: an average maximum of $26.8^{\circ} \mathrm{C}$, an average minimum of $14.4{ }^{\circ} \mathrm{C}$ and an overall average of $19.8^{\circ} \mathrm{C}$. After 4 weeks of inoculation and subsequent nodule formation, 30 seedlings per treatment were transferred from fynbos soil to pots of $7.5 \times 7.5 \times 35 \mathrm{~cm}$ filled with silica sand, and grown for a further 8 weeks in a random block design. One single plant was grown per pot. The seedlings were watered every 3 days with $100 \mathrm{ml}$ of $25 \%$ standard Long Ashton Solution, modified to contain either $50 \mu \mathrm{M}$ P or $500 \mu \mathrm{M}$ P applied as $\mathrm{NaH}_{2} \mathrm{PO}_{4} \cdot 2 \mathrm{H}_{2} \mathrm{O}$. Plants were randomly selected to be harvested after 4 weeks ( 28 days) and at the end of the 8 weeks (56 days). The plant material from both harvests was dried in an oven at $50{ }^{\circ} \mathrm{C}$ and analysed. Similarly, a bulk sample of seed per species was also analysed for macronutrients content and the ratio of $\mathrm{d} 15 \mathrm{~N} / 14 \mathrm{~N}$.

\section{Photosynthetic gas exchange}

Before harvesting, a young and fully expanded leaf of each plant was used for the photosynthetic determinations. Light-response curves were used to determine the irradiance $\left(1300 \mu \mathrm{mol} \mathrm{m} \mathrm{m}^{-2} \mathrm{~s}^{-1}\right)$ at which to conduct the photosynthetic readings at $400 \mathrm{ppm}$ $\mathrm{CO}_{2}$. Readings were taken using a portable infrared gas analyser (Li-Cor, Lincoln, Nebraska, USA). Maximum photosynthesis was recorded at $1300 \mu \mathrm{mol} \mathrm{m}{ }^{-2} \mathrm{~s}^{-1}$ and leaf dark respiration at $0 \mu \mathrm{mol} \mathrm{m} \mathrm{m}^{-2}$.

Calculations of percentage $\mathrm{N}$ derived from the atmosphere (\%NDFA)

The $\delta 15 \mathrm{~N}$ analyses were carried out at the Archeometry Department, University of Cape Town, South Africa. The isotopic ratio of $\delta 15 \mathrm{~N}$ was calculated as $\delta=1000 \%$ o $\left(R_{\text {sample }} / R_{\text {standard }}\right)$, where $\mathrm{R}$ is the molar ratio of the heavier to the lighter isotope of the samples and standards is as defined by Farquhar et al. (1989). Between 2.100 and $2.200 \mathrm{mg}$ of each milled sample were weighed into $8 \mathrm{~mm} \times 5 \mathrm{~mm}$ tin capsules (Elemental Micro-analysis Ltd., Devon, UK) on a Sartorius microbalance (Goettingen, Germany). The samples were then combusted in a Fisons NA 1500 (Series 2) CHN analyser (Fisons instruments SpA, Milan, Italy). The $\delta 15 \mathrm{~N}$ values for the nitrogen gas released were determined on a Finnigan Matt 252 mass spectrometer (Finnigan MAT GmbH, Bremen, Germany), which was connected to a CHN analyser by a Finnigan MAT Conflo control unit. Three standards were used to correct the samples for machine drift: two in-house standards (Merck Gel and Nasturtium) and the IAEA (International Atomic Energy Agency) standard $\left(\mathrm{NH}_{4}\right)_{2} \mathrm{SO}_{4}$.

$\%$ NDFA was calculated according to Shearer and Kohl (1986):

$\% \mathrm{NDFA}=100\left(\left(\delta 15 \mathrm{~N}_{\text {reference }}\right.\right.$ plant $\left.-\delta 15 \mathrm{~N}_{\text {legume }}\right) /$ $\left.\left(\delta 15 \mathrm{~N}_{\text {reference plant }}-\mathrm{B}\right)\right)$ where the reference plant was wheat (Triticum aestivum) grown under the same glasshouse conditions. The $B$-value calculated for this experiment is the $\delta 15 \mathrm{~N}$ natural abundance of the $\mathrm{N}$ derived from biological $\mathrm{N}$ fixation of the aboveground tissue of Virgilia divaricata, grown in a $\mathrm{N}$-free solution.

Nutrient and biomass calculations

(1) Specific $\mathrm{N}$ absorption rate (SNAR) $\left(\mathrm{mg} \mathrm{N} \mathrm{g}^{-1}\right.$ root DW $\mathrm{d}^{-1}$ ) is the calculation of the net $\mathrm{N}$ absorption rate per unit root DW (Nielson et al. 2001):

$$
\begin{aligned}
\mathrm{SNAR}= & {\left[\left(\mathrm{M}_{2}-\mathrm{M}_{1} / t_{2}-t_{1}\right)\right] } \\
& \times\left[\left(\log _{e} R_{2}-\log _{e} R_{1}\right) /\left(R_{2}-R_{1}\right)\right]
\end{aligned}
$$

where $\mathrm{M}$ is the $\mathrm{N}$ content per plant, $t$ is the time and $R$ is the root DW.

(2) Specific Nitrogen utilization rate (SNUR) (g DW $\mathrm{mg}^{-1} \mathrm{~N} \mathrm{~d}^{-1}$ ) is a measure of the DW gained for the $\mathrm{N}$ taken up by the plant (Nielson et al. 2001):

$$
\begin{aligned}
\mathrm{SNUR}= & {\left[\left(\mathrm{W}_{2}-\mathrm{W}_{1} / \mathrm{t}_{2}-\mathrm{t}_{1}\right)\right] } \\
& \times\left[\left(\log _{e} \mathrm{M}_{2}-\log _{e} \mathrm{M}_{1}\right) /\left(\mathrm{M}_{2}-\mathrm{M}_{1}\right)\right]
\end{aligned}
$$

where $\mathrm{M}$ is the $\mathrm{N}$ content and $\mathrm{W}$ is the plant $\mathrm{DW}$. 
Statistical analysis

The effects of the factors and the interactions were tested with a two-way analysis of variance (ANOVA) (SuperAnova, for Macintosh). The means $(n=6)$ were separated using a post hoc Fisher's LSD, multiple range test $(p \leq 0.05)$.

\section{Results}

Biomass accumulation

At the first harvest the Virgilia generally accumulated more biomass in root, shoot and plant components, compared to Acacia at both P supply levels (Table 1; Fig. 1a) and as demonstrated by the greatest root to shoot ratios (Table 1). During this stage, Virgilia also developed more nodules biomass than Acacia in both low $\mathrm{P}$ and high $\mathrm{P}$ soils (Fig. 1c). During the second harvest, Acacia had increased its plant biomass accumulation since the first harvest by $79 \%$, compared to $53 \%$ of Virgilia at high $\mathrm{P}$ (Table 2; Fig. 1a,b). During low $\mathrm{P}$ stress, the increase in Acacia biomass accumulation since the first harvest was $69 \%$, whilst Virgilia's biomass accumulation at low $\mathrm{P}$ was $23 \%$ (Fig. 1a, b). Virgilia developed larger nodules than Acacia at low P levels (Fig. 1d), but the percentage increase from harvest 1 to harvest 2 for Acacia during $\mathrm{P}$ deficiency was $82 \%$ compared to the $50 \%$ increase of Virgilia. Both species under P stress devoted more biomass to root that to shoots (Table 2).
Plant and seed nutrition

During the first harvest, Virgilia had a higher percentage nitrogen derived from atmosphere (\%NDFA) through BNF than Acacia (Fig. 2a), whilst Acacia acquired more (approximately 79\%) $\mathrm{N}$ from soil (Fig. 2a). Although the BNF efficiency was higher in Acacia compared with Virgilia, no statistical differences were detected between these species (Fig. 2c). Compared to Acacia, the seedlings of Virgilia had a lower SNAR at high P (Fig. 3a), but the SNUR of Virgilia at this P level did not differ from Acacia (Fig. 3c). At low P, there was no difference in the SNAR between these species (Fig. 3a), but Virgilia had a higher SNUR (Fig. 3c).

At the second harvest, Acacia relied less on BNF for $\mathrm{N}$ acquisition (Fig. 2b) and also had a lower efficiency for BNF compared to Virgilia (Fig. 2d) at high P. This concurred with an increase in Acacia SNAR compared to Virgilia (Fig. 3b), but was not translated into greater utilization for growth as evidenced by the SNUR (Fig. 3d). In contrast to high $\mathrm{P}$, Acacia had more reliance on BNF under low $\mathrm{P}$ conditions, whilst Virgilia showed no change in its BNF dependence with $\mathrm{P}$ variation (Fig. 2b). The BNF efficiency of Acacia was unaffected by P levels, but the Virgilia had a decrease in efficiency under P stress (Fig. 2d). The SNAR did not differ between Virgilia and Acacia under P stress, and this concurred with the unchanged SNUR for the species (Fig. 3b; d).

Seed nutritional status was significantly different between species. Seed from Virgilia had significantly

Table 1 Biomass and nitrogen concentrations of Acacia saligna and Virgilia divaricata at harvest 1 after 28 days of receiving either $500 \mu \mathrm{M}$ P or $50 \mu \mathrm{M}$ P nutrient solutions

\begin{tabular}{|c|c|c|c|c|c|c|c|c|c|}
\hline Treatment & $\begin{array}{l}\text { Specific leaf } \\
\text { mass }\left(\mathrm{g} / \mathrm{m}^{2}\right)\end{array}$ & $\begin{array}{l}\text { Nodulated } \\
\text { roots }(\mathrm{g})\end{array}$ & $\begin{array}{l}\text { Shoot } \\
\text { weight } \\
\text { (g) }\end{array}$ & $\begin{array}{l}\text { Nodule } \\
\text { weight } \\
\text { (g) }\end{array}$ & $\begin{array}{l}\text { Nodule per } \\
\text { shoot }(g / g)\end{array}$ & $\begin{array}{l}\text { Root growth } \\
\text { rate } \mathrm{mg} / \\
\text { g/day }\end{array}$ & $\begin{array}{l}\text { Shoot growth } \\
\text { rate mg/ } \\
\text { g/day }\end{array}$ & $\begin{array}{l}\text { Plant growth } \\
\text { rate mg/ } \\
\text { g/day }\end{array}$ & $\begin{array}{l}\text { Plant N } \\
\mathrm{mmol} / \mathrm{g}\end{array}$ \\
\hline \multicolumn{10}{|l|}{$500 \mu \mathrm{M} P$} \\
\hline Acacia & $22^{\mathrm{a}}$ & $0.022^{\mathrm{a}}$ & $0.050^{\mathrm{a}}$ & $0.007^{\mathrm{a}}$ & $0.135^{\mathrm{a}}$ & $107^{\mathrm{a}}$ & $55^{\mathrm{b}}$ & $66^{\mathrm{a}}$ & $16^{\mathrm{b}}$ \\
\hline Virgilia & $30^{\mathrm{b}}$ & $0.118^{\mathrm{b}}$ & $0.143^{\mathrm{b}}$ & $0.022^{\mathrm{b}}$ & $0.179^{\mathrm{b}}$ & $212^{\mathrm{ab}}$ & $95^{\mathrm{c}}$ & $135^{\mathrm{b}}$ & $12^{\mathrm{a}}$ \\
\hline \multicolumn{10}{|l|}{$50 \mu \mathrm{M} P$} \\
\hline Acacia & $23^{\mathrm{a}}$ & $0.014^{\mathrm{a}}$ & $0.031^{\mathrm{A}}$ & $0.004^{\mathrm{a}}$ & $0.139^{\mathrm{a}}$ & $54^{\mathrm{a}}$ & $25^{\mathrm{a}}$ & $31^{\mathrm{a}}$ & $14^{\mathrm{ab}}$ \\
\hline Virgilia & $28^{\mathrm{b}}$ & $0.178^{\mathrm{b}}$ & $0.173^{\mathrm{B}}$ & $0.026^{\mathrm{b}}$ & $0.150^{\mathrm{b}}$ & $337^{\mathrm{b}}$ & $104^{\mathrm{c}}$ & $169^{\mathrm{b}}$ & $11^{\mathrm{a}}$ \\
\hline
\end{tabular}

Values are presented as means $(n=6)$ and letters along each data column indicate significant differences among treatments using the post hoc Fisher's LSD, multiple range test $(p \leq 0.05)$ 

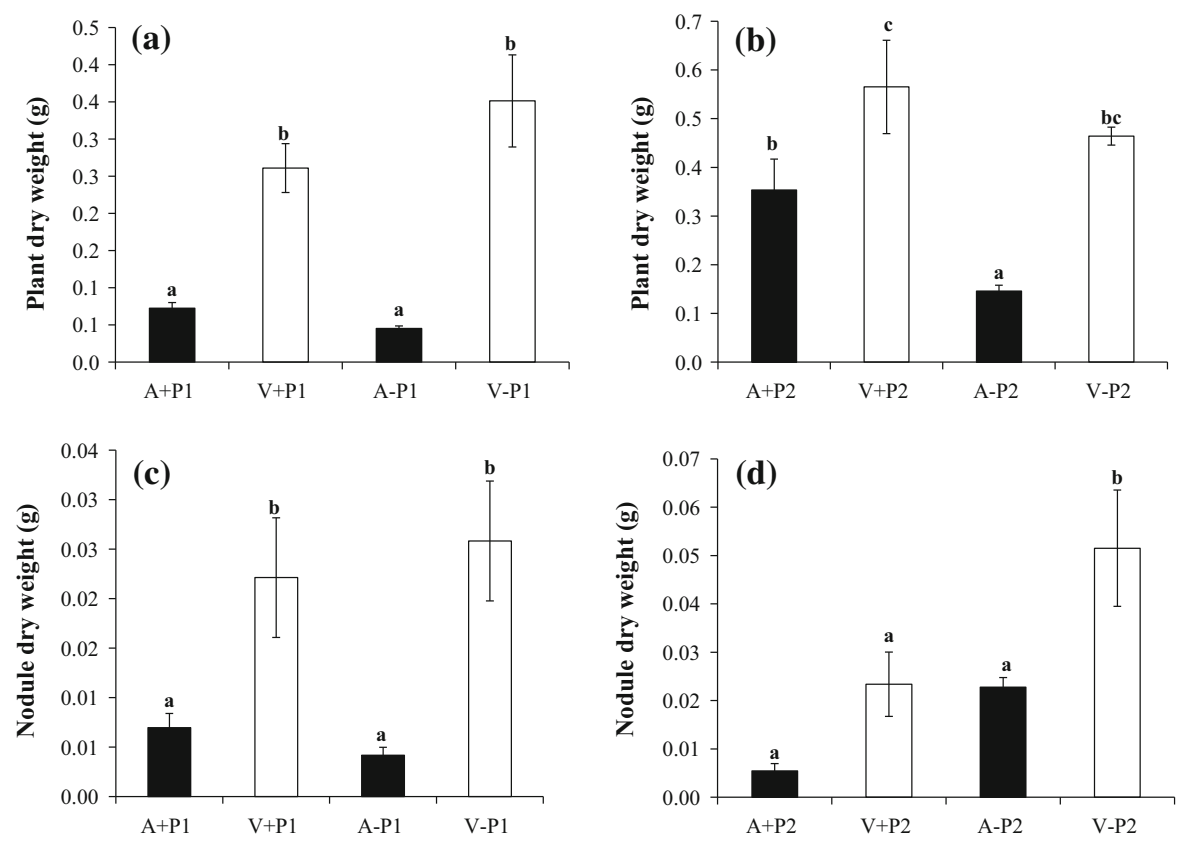

Fig. 1 Plant and nodule dry weights of Acacia saligna (a) and Virgilia divaricata $(\mathrm{V})$ after receiving either $500 \mu \mathrm{M} \mathrm{P}(+\mathrm{P})$ or $50 \mu \mathrm{MP}(-\mathrm{P})$ nutrient solutions for a period of 28 days $(\mathbf{a}, \mathbf{c})$ or 56 days (b, d) before each respective harvest. Values are

presented as means $(n=4)$ with standard error bars and letters indicate significant differences among treatments using the post hoc Fisher's LSD, multiple range test $(p \leq 0.05)$

Table 2 Biomass and nitrogen concentrations of Acacia saligna and Virgilia divaricata at harvest 2 after 56 days of receiving either $500 \mu \mathrm{M}$ P or $50 \mu \mathrm{M}$ P nutrient solutions

\begin{tabular}{|c|c|c|c|c|c|c|c|c|c|}
\hline Treatment & $\begin{array}{l}\text { Specific } \\
\text { leaf mass } \\
\left(\mathrm{g} / \mathrm{m}^{2}\right)\end{array}$ & $\begin{array}{l}\text { Nodulated } \\
\text { roots }(\mathrm{g})\end{array}$ & $\begin{array}{l}\text { Shoot } \\
\text { weight }(g)\end{array}$ & $\begin{array}{l}\text { Nodule } \\
\text { weight (g) }\end{array}$ & $\begin{array}{l}\text { Nodule per } \\
\text { shoot }(\mathrm{g} / \mathrm{g})\end{array}$ & $\begin{array}{l}\text { Root } \\
\text { growth } \\
\text { rate }(\mathrm{mg} / \\
\text { g/day) }\end{array}$ & $\begin{array}{l}\text { Shoot } \\
\text { growth } \\
\text { rate (mg/ } \\
\text { g/day) }\end{array}$ & $\begin{array}{l}\text { Plant } \\
\text { growth } \\
\text { rate }(\mathrm{mg} / \\
\text { g/day) }\end{array}$ & $\begin{array}{l}\text { Plant N } \\
\text { (mmol/ } \\
\mathrm{g})\end{array}$ \\
\hline
\end{tabular}

$500 \mu \mathrm{M} \mathrm{P}$

\begin{tabular}{|c|c|c|c|c|c|c|c|c|c|c|c|c|c|c|c|c|c|c|c|}
\hline Acacia & 40 & $\mathrm{~b}$ & 0.091 & & $\mathrm{a}$ & 0.218 & $a b$ & 0.005 & $\mathrm{a}$ & 0.034 & $\mathrm{a}$ & 625 & $\mathrm{~b}$ & 415 & $\mathrm{~b}$ & 461 & $\mathrm{~b}$ & 21 & $\mathrm{c}$ \\
\hline Virgilia & 26 & a & 0.181 & & $\mathrm{~b}$ & 0.384 & $\mathrm{c}$ & 0.023 & $\mathrm{a}$ & 0.058 & $\mathrm{a}$ & 265 & $\mathrm{a}$ & 226 & $\mathrm{a}$ & 237 & $\mathrm{a}$ & 19 & bc \\
\hline \multicolumn{20}{|l|}{$50 \mu \mathrm{M} \mathrm{P}$} \\
\hline Acacia & 38 & $b$ & 0.077 & $\mathrm{a}$ & & 0.096 & $\mathrm{a}$ & 0.023 & $\mathrm{a}$ & 0.266 & $\mathrm{~b}$ & 402 & $\mathrm{a}$ & 104 & $\mathrm{a}$ & 169 & $\mathrm{a}$ & 17 & $\mathrm{~b}$ \\
\hline Virgilia & 35 & $a b$ & 0.207 & & $\mathrm{~b}$ & 0.258 & $\mathrm{bc}$ & 0.052 & $\mathrm{~b}$ & 0.208 & $\mathrm{~b}$ & 354 & $\mathrm{a}$ & 172 & $\mathrm{a}$ & 235 & $\mathrm{a}$ & 10 & $\mathrm{a}$ \\
\hline
\end{tabular}

Values are presented as means $(n=6)$ and letters along each data column indicate significant differences among treatments using the post hoc Fisher's LSD, multiple range test $(\mathrm{P} \leq 0.05)$

more $\mathrm{P}$ and $\mathrm{N}$ than seed of Acacia. Similarly, the $\mathrm{C}$ content was greater in Virgilia seed than in Acacia, although no significant differences were observed. Atmospheric $\mathrm{N}$ was significantly higher in Virgilia compared with Acacia (Table 3).

\section{Leaf gas exchange}

At the first harvest, there were no significant differences in the photosynthetic (pm) rates (Fig. 4a) and leaf dark respiration rates (dr) (Fig. 4c) between Virgilia and Acacia at either high or low P supply levels. However, the comparison of the proportion of photosynthetic $\mathrm{C}$ gain relative to respiratory $\mathrm{C}$ loss 
Fig. 2 Biological nitrogen fixation, as percentage $\mathrm{N}$ derived from atmosphere $(\%$ NDFA) and efficiency of biological nitrogen fixation (BNF), as delta $\mathrm{N}^{15}$ per unit nodule of Acacia saligna

(a) and Virgilia divaricata

(V) after receiving either

$500 \mu \mathrm{M}$ P $(+\mathrm{P})$ or $50 \mu \mathrm{M} \mathrm{P}$

$(-\mathrm{P})$ nutrient solutions for a period of 28 days $(\mathbf{a}, \mathbf{c})$ or 56 days $(\mathbf{b}, \mathbf{d})$ before each respective harvest. Values are presented as means $(n=4)$ with standard error bars and letters indicate significant differences among treatments using the post hoc Fisher's LSD, multiple range test $(p \leq 0.05)$

Fig. 3 Specific plant nitrogen absorption rates (SNAR) and specific plant nitrogen utilization rates (SNUR) of Acacia saligna (a) and Virgilia divaricata (V) after receiving either $500 \mu \mathrm{MP}(+\mathrm{P})$ or $50 \mu \mathrm{M} \mathrm{P}$ $(-\mathrm{P})$ nutrient solutions for a period of 28 days $(\mathbf{a}, \mathbf{c})$ or 56 days $(\mathbf{b}, \mathbf{d})$ before each respective harvest. Values are presented as means $(n=4)$ with standard error bars and letters indicate significant differences among treatments using the post hoc Fisher's LSD, multiple range test $(p \leq 0.05)$
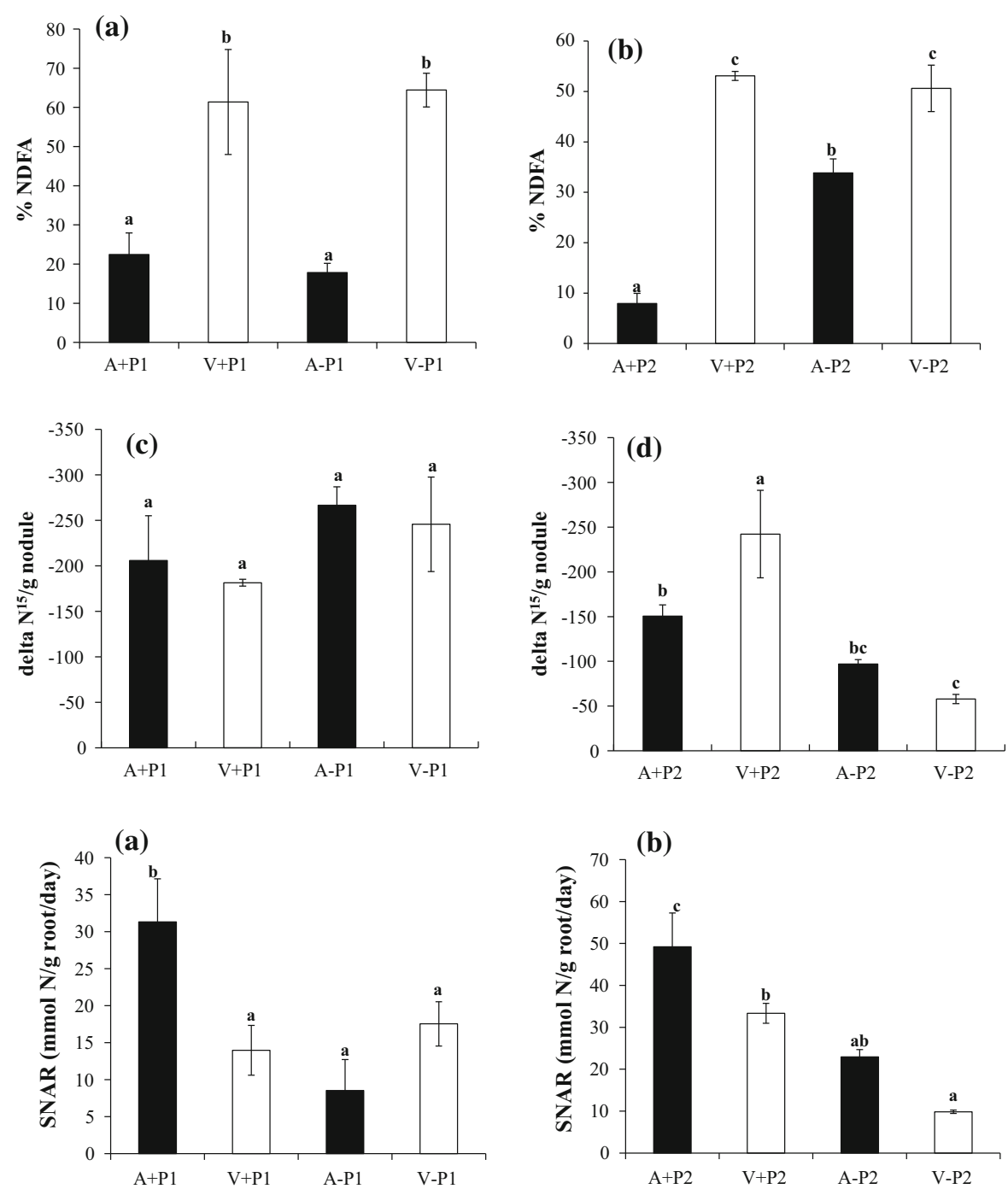

(b)
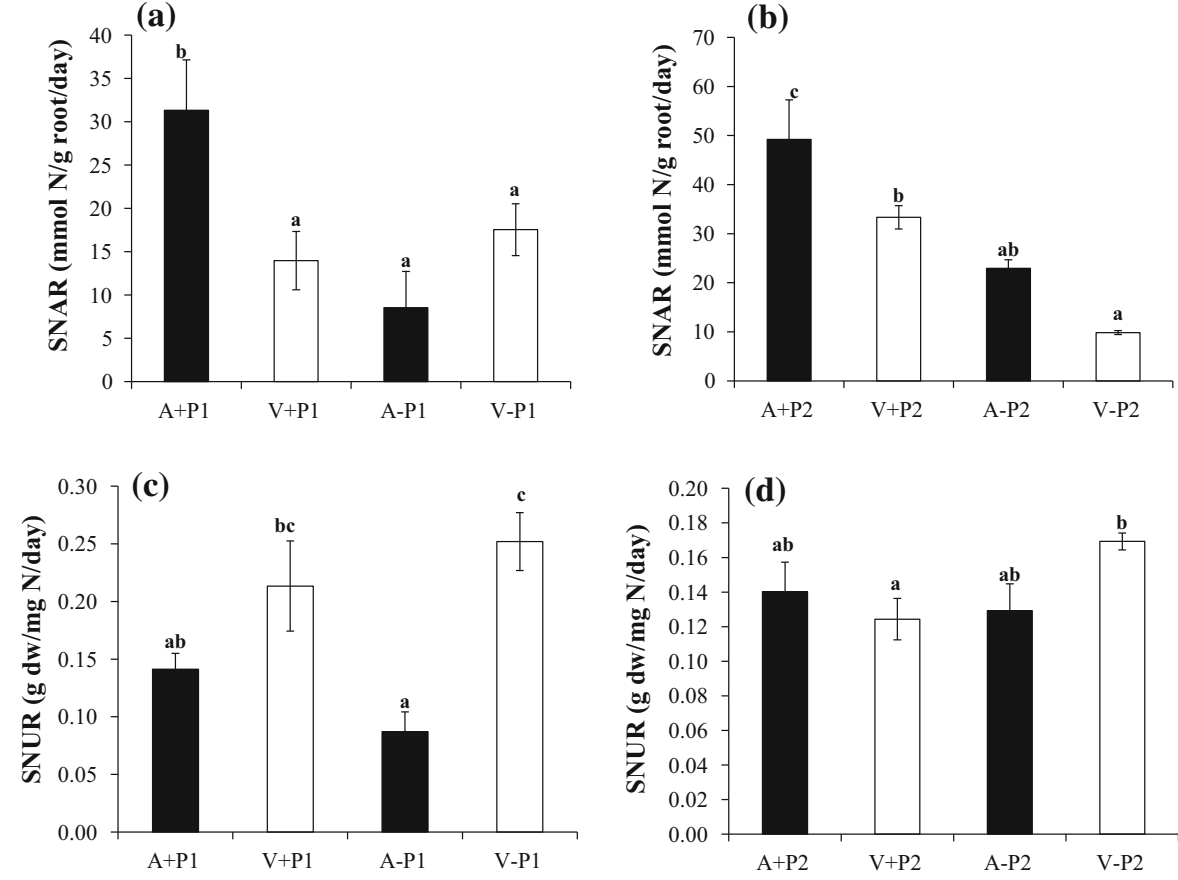

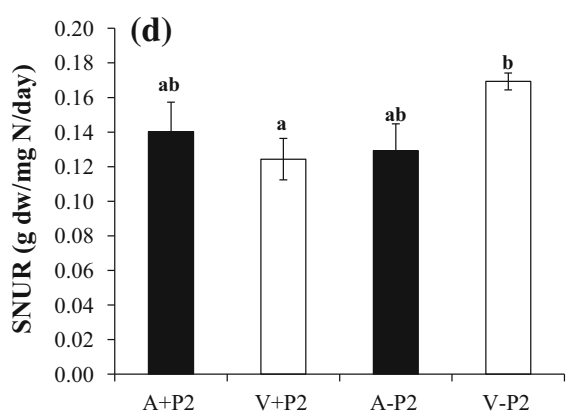

indicate that Virgilia maintained a higher ratio of photosynthesis: respiration (pm:dr) than Acacia only at high P levels, whilst Acacia remained as competitive as Virgilia for positive leaf $\mathrm{C}$ gain at low $\mathrm{P}$ (Fig. 5a). The second harvest revealed that, under high
$\mathrm{P}$ condition, Acacia had a higher pm rate compared to Virgilia (Fig. 4b). Although the pm rates were lower in both plants under P stress, there were no differences between the two species (Fig. 4b). Following the trend of the pm rates, the dr rates were also lower in the $\mathrm{P}$ 
Table 3 Biomass and nitrogen concentrations of Acacia saligna and Virgilia divaricata seeds

\begin{tabular}{llllrl}
\hline Seed material & $\% \mathrm{P}$ & $\% \mathrm{~N}$ & $\% \mathrm{C}$ & $\mathrm{d} 15 \mathrm{~N} / 14 \mathrm{~N}$ & $\mathrm{C}: \mathrm{N}$ \\
\hline Acacia & $0.29 \mathrm{a}$ & $3.76 \mathrm{a}$ & $43.32 \mathrm{a}$ & $0.19 \mathrm{a}$ & $11.53 \mathrm{a}$ \\
Virgilia & $0.47 \mathrm{~b}$ & $5.23 \mathrm{~b}$ & $47.10 \mathrm{a}$ & $-1.56 \mathrm{a}$ & $9.01 \mathrm{~b}$ \\
\hline
\end{tabular}

Values are presented replicate samples $(n=6)$ and letters along each data column, indicate significant differences between species using the post hoc Fisher's LSD, multiple range test $(p \leq 0.05)$

deficient plants of both species (Fig. 4d). Under high P, Virgilia had a higher dr loss than Acacia (Fig. 4d) but this was reversed under low P. Under low $\mathrm{P}$, these leaf gas exchange alterations resulted in a lower ratio of photosynthetic $\mathrm{C}$ gain relative to respiratory $\mathrm{C}$ loss, in Acacia than in Virgilia (Fig. 5b). However, at high $\mathrm{P}$, Acacia leaves had a greater ratio of photosynthetic $\mathrm{C}$ gain relative to respiratory $\mathrm{C}$ loss, compared to Virgilia leaves (Fig. 5b).

\section{Discussion}

This work highlights the importance of using localscale factors such as soil quality to forecast the invasive potential of highly invasive species. The research has established that the success of the invasive legume, Acacia saligna, depends on the mechanisms and cost of mineral nutrition under different soil $\mathrm{P}$ conditions.

Nutrient acquisition by plants is subject to three main factors: structure of the roots, the soil nutrient content and the ability of the plant to form specialized associations for the acquisition of nutrients (Morris et al. 2011). Legumes fulfil their $\mathrm{N}$ requirements by combining two strategies of acquisition of this mineral: (1) the direct uptake from the soil where the mineral is present from different sources and (2) the fixing of atmospheric $\mathrm{N}$ through BNF (Vance 2001). In terms of $\mathrm{N}$ nutrition, the soil $\mathrm{N}$ acquisition method is energetically more cost-effective to legume than BNF (Pate et al. 1979; Kaschuk et al. 2009; PérezFernández et al. 2016; Ndzwanana et al. 2019). However, in N-poor soils, the more energetically expensive BNF becomes imperative for plant survival. With legumes only establishing their specialized symbiotic relationships with $\mathrm{N}$-fixing bacteria when their roots have been established, seedlings rely on seed mineral reserves for the first few weeks of growth (Mortimer et al. 2008; Pérez-Fernández et al. 2016; Ndzwanana et al. 2019). During the initial stages of seedling growth, larger seeds are generally more
Fig. 4 Leaf photosynthetic rates $(\mathrm{pm})$ and leaf dark respiration rates $(\mathrm{dr})$ of Acacia saligna (a) and Virgilia divaricata $(\mathrm{V})$ after receiving either $500 \mu \mathrm{M} \mathrm{P}$ $(+\mathrm{P})$ or $50 \mu \mathrm{M} \mathrm{P}(-\mathrm{P})$ nutrient solutions for a period of 28 days $(\mathbf{a}, \mathbf{c})$ or 56 days $(\mathbf{b}, \mathbf{d})$ before each respective harvest. Values are presented as means $(n=4)$ with standard error bars and letters indicate significant differences among treatments using the post hoc Fisher's LSD, multiple range test $(p \leq 0.05)$
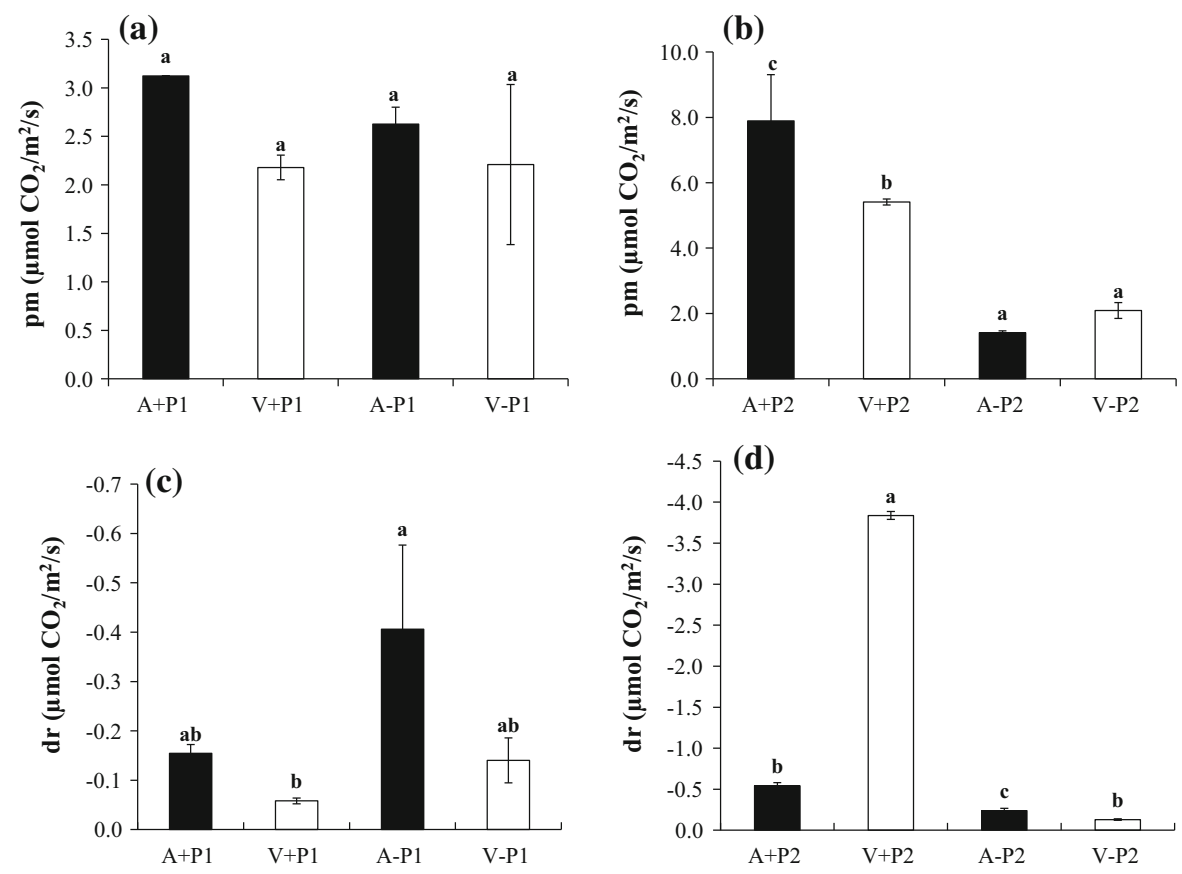


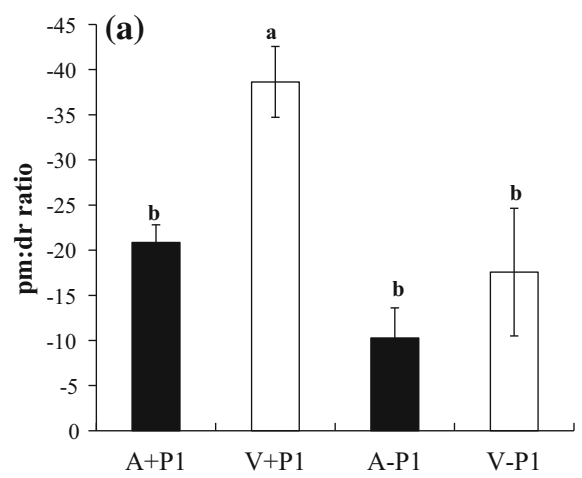

Fig. 5 Leaf photosynthetic: dark respiration ratio (pm:dr) of Acacia saligna (a) and Virgilia divaricata $(\mathrm{V})$ after receiving either $500 \mu \mathrm{M} \mathrm{P}(+\mathrm{P})$ or $50 \mu \mathrm{MP}(-\mathrm{P})$ nutrient solutions for a period of 28 days (a) or 56 days (b) before each respective

beneficial in nutrient-limited conditions than smaller seeds as they accumulate more mineral reserves in their cotyledons (Milberg et al. 1998). In a study by Hanley et al. (2007), Australian Fabaceae showed a significant positive relationship between seed size and the growth rate of seedlings. Our analyses of Virgilia and Acacia seed compositions was in accordance with Hanley et al. (2007) where the larger Virgilia seeds contained more macronutrients than the smaller Acacia seeds. Many studies, however, have confirmed that Acacia spp. are able to compensate for the reduced seed nutrient accumulation by having more prolific seed production than indigenous species (Morris et al. 2011) which leads to the rapid establishment of seed banks and gives Acacia a competitive advantage based on seed quantity rather than quality. The seed $\mathrm{N}$ isotope values data (Table 3) indicate that Virgilia relies more on BNF and less on soil $\mathrm{N}$ uptake. This means that there is more $\mathrm{N}$ coming from biological fixation available to meet the plants requirements, one of which is to fill the seeds. $\mathrm{N}$ contribution-derived BNF to seeds is energetically more costly and instigates the trade-off between quality and quantity of seeds, probably restricting Virgilia to producing less, but higher quality seeds compared to the Acacia plant.

The benefits of more nutrient-rich seeds of Virgilia compared to invasive Acacia can be explored in terms of the ability of the seedlings to survive in soils that are P-sufficient and constrained by low P. Subsequently, during the first two months after germination at the first harvest, the larger mineral storage in Virgilia seeds relative to Acacia benefited the initial growth of

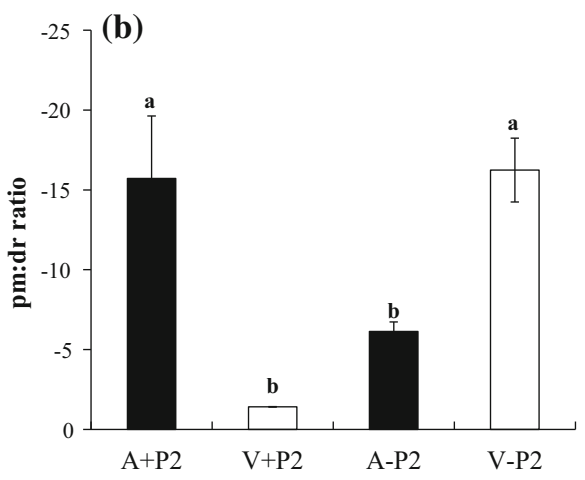

harvest. Values are presented as means $(n=4)$ with standard error bars and letters indicate significant differences among treatments using the post hoc Fisher's LSD, multiple range test $(p \leq 0.05)$

Virgilia in low $\mathrm{P}$ as well as high $\mathrm{P}$ soils (Fig. 1; Table 3). During this stage, the larger biomass of all plant organs of Virgilia compared to Acacia can be ascribed to several factors related to nutrition, photosynthetic and respiratory costs (Table 1). During this period, the larger nodules of Virgilia relative to Acacia, under both P conditions, had a major contribution to the higher \%NDFA in the Virgilia at both concentrations of P. In contrast, Acacia relied less on $\mathrm{BNF}$ for its $\mathrm{N}$ requirements, and the nodules also had no change in their efficiency for BNF during the variation in $\mathrm{P}$ supply (Fig. 2). Despite the higher specific nitrogen acquisition rate (SNAR) of Acacia at high $\mathrm{P}$, this was not translated into a greater utilization of $\mathrm{N}$ for growth, as evidenced by the specific nitrogen utilization rate (SNUR). In contrast to the Acacia at low P supply, the seedlings of Virgilia had a much higher utilization of its acquired $\mathrm{N}$ for growth despite the similar SNAR in both plants (Fig. 3). Since the Virgilia seedlings acquired more $\mathrm{N}$ from BNF, the increased SNUR can be attributed to the enhanced reliance on BNF. At high $\mathrm{P}$ supply, the growth advantage of Virgilia may have been underpinned by the relative contributions of photosynthesis (pm) and leaf dark respiration (dr) to the above-ground $\mathrm{C}$ balance (Fig. 4). Compared to Acacia, Virgilia maintained a higher ratio of pm:dr at high $\mathrm{P}$ level (Fig. 5). This ratio is important in determining the $\mathrm{C}$ available for growth, since $30-70 \%$ of photosynthetically gained $\mathrm{C}$ can be lost via respiration, of which 50-70\% can occur in above-ground tissues (Atkin and Macherel 2009). This initial growth advantage of Virgilia plants over Acacia plants may have been an 
early developmental benefit, being strongly influenced by the more nutrient-rich seeds of Virgilia in a nutrient-poor soil. However, this early developmental benefit was not sustained during later stages of growth.

During later growth stages, as evidenced by the second harvest in the third month, the Acacia seedlings showed an increase in biomass, which challenged the initial biomass advantage of the Virgilia seedlings (Table 2). In this regard, the increase in biomass of Acacia seedlings since the first harvest at both levels of $\mathrm{P}$ was underpinned by several physiological mechanisms at low and high P levels. The Acacia plants showed two separate strategies at low $\mathrm{P}$ and high $\mathrm{P}$ levels to achieve the increases in growth. In the first strategy at high $\mathrm{P}$, the Acacia's growth spurt is based on alterations in the source of $\mathrm{N}$ acquisition and $\mathrm{C}$ balance. Relative to Virgilia, Acacia relied less on BNF for $\mathrm{N}$ uptake and therefore had a lower BNF efficiency and less atmospheric $\mathrm{N}$ accumulated in the seed. This relates to Acacia maintaining a higher SNAR than Virgilia, suggesting that Acacia acquired more $\mathrm{N}$ from soil sources. Since soil $\mathrm{N}$ acquisition and assimilation are usually energetically less expensive than BNF (Pate et al. 1979; Kaschuk et al. 2009), this reduced $\mathrm{C}$ cost for $\mathrm{N}$ nutrition contributed to the increase in plant growth. Furthermore, the greater ratio of pm:dr in Acacia than in Virgilia explains the greater $\mathrm{C}$ balance in the shoots, since these structures can contribute up $50-70 \%$ of plant respiratory losses (Atkin and Macherel 2009). In the second strategy under low $\mathrm{P}$ conditions, the Acacia's growth is based on greater investment to acquire nitrogen from the atmosphere. In this regard, Acacia allocated more growth to roots and to nodules (Table 2) during $\mathrm{P}$ stress compared to high $\mathrm{P}$ conditions, which resulted in more reliance on BNF for $\mathrm{N}$ nutrition. This concurs with work showing that invasive Australian Acacia invest substantially in belowground organs compared to indigenous species (Morris et al. 2011). Acacia, however, was likely to still have obtained $\mathrm{N}$ from both atmospheric and soil sources, but its \% NDFA was approximately $30 \%$ at low $\mathrm{P}$ compared to ca. $8 \%$ at high $\mathrm{P}$ levels.

Our findings shed light on the reasons why Acacia, once established, can grow faster to become taller than indigenous species, out-competing them for light, water and essential nutrients (Morris et al. 2011). The positive trend of Acacia in reducing the growth advantage of Virgilia continues with age to overtake the initial Virgilia advantage as seen in the field (personal observation). This concurs with studies by Musil (1993) and Witkowski (1991) which showed that seedling and adult Acacia leaves have a much higher concentration of $\mathrm{N}$ and $\mathrm{K}$ levels than indigenous species in invaded areas of the CFR.

This study has found that Acacia, besides being notorious for rapidly building up large seed banks, also employs two different strategies for survival in high and low $\mathrm{P}$ level soils, making them even more successful than indigenous species in more than one soil type. Thus it seems that Virgilia divaricata will be unable to compete with the presence of Acacia saligna in the CFR and other Mediterranean climate regions are definitely at risk when considering the possible invasion by Acacia in their soils.

Analysing the competitive ability of exotic species compared to native species allows us to assess the invasive potential of an introduced species. Additionally, it shows how susceptible the local species are to displacement by the exotic species. This makes it possible to identify and prioritize action plants against invasive species (Pérez-Fernández and Lamont 2016). Our findings stress the importance of both the plants' metabolic traits and the nutritional status of the soil in defining the competitive ability of a given species in a particular location. Acacia is able to build a solid root system that guarantees its permanence in the invaded soils and this can be seen at early stages in seedling of only 12 weeks. This suggests that changing the nutritional status of the soils where the invaders occur, or pulling them out to complete remove their root systems, could be strategies to consider in the control of Acacia in the fynbos biome. We acknowledge the importance of considering other factors such as climatic models or soil characteristics (Thuiller et al. 2005), although local environmental traits clearly also modulate how invasive species behave compared to native ones. Therefore, local environmental traits such as nutrient availability, climatic variations or a combination of both should be taken into account when designing management plans to control invasiveness.

Acknowledgements One of the authors (N.E.) would like to acknowledge the South African Association of Botanists (SAAB) for a bursary to support her studies. The authors declare no conflict of interest.

Funding This study was financially supported by the National Research Foundation of South Africa (NRF FA2007042200001) 
and glasshouse and laboratory facilities were provided by the Department of Botany and Zoology, Stellenbosch University.

\section{References}

Aronson J, Ovalle C, Avendano J (1993) Ecological and economic rehabilitation of degraded 'Espinales' in the subhumid Mediterranean-climate region of central Chile. Landsc Urban Plan 24:15-21

Atkin OK, Macherel D (2009) The crucial role of plant mitochondria in orchestrating drought tolerance. Ann Biol 103:518-597

Bethlenfalvay GJ, Phillip DA (1977) Ontogenetic interactions between photosynthesis and symbiotic nitrogen fixation in legumes. Plant Physiol 60:419-421

Blackburn TM, Pysek P, Bacher S, Carlton JT, Duncan RP, Jarosik V, Wilson JRU, Richardson DM (2011) A proposed unified framework for biological invasions. Trends Ecol Evol 26:333-339

Bucher M (2006) Functional biology of plant phosphate uptake at root and mycorrhiza interfaces. New Phytol 173:11-26

Callaway RM, Ridenour W (2004) Invasive success and the evolution of increased competitive ability author(s): Ragan M. Callaway and Wendy M. Ridenour Source. Front Ecol Environ 2:436-443

Callaway RM, Walker LR (1997) Competition and facilitation: a synthetic approach to interactions in plant communities. Ecology 78:1958-1965

Campbell BM, Moll J (1977) The forest communities of Table Mountain, South Africa. Vegetatio 43:105-115

Coetsee C, Wigley BJ (2013) Virgilia divaricate may facilitate forest expansión in the agrotemperate forests of the southern Cape, South Africa. Koedoe 55: 1128

Corbin JD, D'Antonio CM (2004) Effects of exotic species on soil nitrogen cycling: Implications for restoration. Weed Technol 18:1464-1467

Costello D (2000) Effects of invasion by the indigenous shrub Acacia sophorae on plant composition of coastal grasslands in south-eastern Australia. Biol Conserv 96:113-121

Cowling RM, Pressey RL, Rouget M, Lombard AT (2003) A conservation plan for a global biodiversity hotspot-the Cape Floristic Region, South Africa. New Phytol 112:191-216

Davidson BR, Davidson HF (1993) Legumes: the Australian experience. Research Studies Press, Somerset

Goldblatt P (1997) Floristic diversity in the Cape flora of South Africa. Biodiversity Conserv 6:359-377

Goldblatt P, Manning JC (2002) Plant diversity of the Cape region of southern Africa. Ann Missouri Bot Gard 89:281-302

Hanley ME, Cordier PK, May O, Kelly CK (2007) Seed size and seedling growth: differential response of Australian and British Fabaceae to nutrient limitation. New Phytol 174:381-388

Herrera AM, Carruthers RI, Mills NJ (2011) Introduced populations of Genista monspessulana (French broom) are more dense and produced a greater seed rain in California, USA, than native populations in the Mediterranean Basin of Europe. Biol Invasions 13:369-380
Holmes P, Cowling RM (1997) The effects of invasion of Acacia saligna on the guild structure and regeneration capabilities of South African fynbos shrublands. J Appl Ecol 34:317-332

Hoque MS, Broadhurst LM, Thrall PH (2010) Genetic characterisation of root nodule bacteria associated with Acacia salicina and A. stenophylla (Mimosaceae) across southeastern Australia. Int J Syst Evol Microbiol 61:299-309

Israel DW (1987) Investigation of the role of phosphorus in symbiotic dinitrogen fixation. Plant Physiol 84:835-840

Jacobs G, Weber E, Edwards PJ (2014) Introduced plants of the invasive Solidago gigantea (Asteracea) are larger and grow denser than conspecifics in the native range. Divers Distrib 10:11-19

Kaschuk G, Kuyper TW, Leffelaar PA, Hungria M, Giller KE (2009) Are the rates of photosynthesis stimulated by the carbon sink strength of rhizobial and arbuscular mycorrhizal symbioses? Soil Biol Biochem 41:1233-1244

Kirkwood D, Wessels N, Le Maitre D, Picker M (2014) Aliens and their management. In: Esler KJ, Pierce SM, De Villiers $\mathrm{C}$ (eds) Fynbos ecology and management. Briza, Pretoria

Le Roux MR, Kahn S, Valentine AJ (2008) Organic acid accumulation inhibits $\mathrm{N}_{2}$-fixation in P-stressed lupin nodules. New Phytol 177:956-964

Le Roux JJ, Mavengere NR, Ellis AG (2016) The structure of legume-rhizobium intraction networks and their response to tree invations. AoB Plants 8: plw038

Levine JM, Vilá M, D’Antonio CM, Dukes JS, Grigulis K, Lavorel S (2003) Mechanisms underlying the impacts of exotic plant invasions. P Roy Soc London 270:775-781

Lorenzo P, Rodríguez-Echeverría S, González L, Freitas H (2010) Effect of invasive Acacia dealbata Link on soil microorganisms as determined by PCR-DGGE. Appl Soil Ecol 44:245-251

Lowe SR, Woodford DJ, Impson DN, Day JA (2008) The impact of invasive fish and invasive riparian plants on the invertebrate fauna of the Rondegat River, Cape Floristic Region, South Africa. Afr J Aquat Sci 33:51-62

Maistry PM, Cramer MD, Chimphango SBM (2013) N and P colimitation of $\mathrm{N}_{2}$-fixing and $\mathrm{N}$-supplied fynbos legumes from the Cape Floristic Region. Plant Soil 373:217-228

Milberg P, Pérez-Fernández MA, Lamont BB (1998) Seedling growth response to added nutrients depends on seed size in three woody genera. J Ecol 86:624-632

Mitchell OG, Power AG (2003) Release of invasive plants from fungal and viral pathogens. Nature 421:625-627

Morris TL, Esler KJ, Barger NN, Jacobs SM, Cramer MD (2011) Ecophysiological traits associated with the competitive ability of invasive Australian Acacias. Diversity Distrib 17:898-910

Mortimer PE, Pérez-Fernández MA, Valentine AJ (2008) The role of arbuscular mycorrhizal colonization in the carbon and nutrient economy of the tripartite symbiosis with nodulated Phaseolus vulgaris. Soil Biol Biochem 40:1019-1027

Musil CF (1993) Effect of invasive Australian Acacias on the growth and nutrient chemistry of South African lowland fynbos. J Appl Ecol 30:361-372

Myers N, Mittermeier RA, Mittermeier CG, Da Fonseca GAB, Kent J (2000) Biodiversity hotspots for conservation priorities. Nature 403:853-858 
Ndzwanana Z, Tsvuura Z, Valentine AJ, Pérez-Fernández MA, Magadlela A (2019) Differential patterns of nitrogen nutrition and growth cost of the indigenous Vachellia sieberiana and the introduced Chromolaena odorata in the savannah environment. AoB Plants 11: plz008

Nielson KL, Amram E, Lynch JP (2001) The effect of phosphorous availability on the carbon economy of contrasting common bean (Phaseolus vulgaris L.) genotypes. J Exp Bot 52:329-339

Oliviera M, Tejera C, Iribarne A, LIuch C (2004) Growth, nitrogen fixation and ammonium assimilation in common bean (Phaseolus vulgaris): effect of phosphorus. Physiol Plant 121:498-505

Pate JS, Layzell DB, Atkins CA (1979) Economy of carbon and nitrogen in a nodulated and non-nodulated $\left(\mathrm{NO}_{3}\right.$-grown) legume. Plant Physiol 64:1083-1088

Pereira PAA, Bliss FA (1987) Nitrogen fixation and plant growth of common bean (Phaseolus vulgaris L.) at different levels of phosphorus availability. Plant Soil 104:79-84

Pérez-Fernández MA, Lamont B (2016) Competition and facilitation between Australian and Spanish legumes in seven Australian soils. Plant Species Biol 31:256-271

Pérez-Fernández MA, Calvo-Magro E, Ramírez-Rojas I, Moreno-Gallardo L, Valentine A (2016) Patterns of growth costs and Nitrogen acquisition in Cytisus striatus (Hill) Rothm. and Cytisus balansae (Boiss.) ball are mediated by sources of inorganic N. Plants 5(2), 20:2-11.

Power A (2010) Ecosystem services and agriculture: tradeoffs and synergies. Phyl Trans Royal Soc B. https://doi.org/10. 1098/rstb.2010.0143

Ragothama KG (1999) Phosphate acquisition. Annu Rev Plant Physiol Plant Mol Biol 5:665-693

Read DJ, Mitchell DT (1983) Decomposition and mineralization processes in Mediterranean-type ecosystems and in the heathlands of similar structure. In: Kruger FJ, Mitchell DT, Jarvis JUM (eds) Mediterranean type ecosystems: the role of nutrients. Springer, Berlin

Rebelo AG, C. Boucher C, Helme NA, Mucina L., Rutherford MC (2006) In Fynbos biome: the vegetation of South Africa, Lesotho and Swaziland. L. Mucina and M. C. Rutherford, editors. Strelitzia 19. South African National Biodiversity Institute, Pretoria

Reinhart KO, Callaway RM (2003) Soil biota facilitate exotic Acer invasions in Europe and North America. Ecol Appl 14:1737-1745

Richardson DM (2001) Plant invasions. In: Levin S (ed) Encyclopaedia of biodiversity, vol 4. Academic Press, San Diego
Richardson DM, Van Wilgen BW (2004) Invasive alien plants in South Africa: how well do we understand the ecological impacts? S Afr J Sci 100:45-52

Richardson DM, Allsopp N, D'Antonio CM, Milton SJ (2000) Plant invasions - the role of mutualisms. Biol Rev 75:65-93

Shearer GB, Kohl DM (1986) $\mathrm{N}_{2}$-fixation in the field settings: estimations based on natural ${ }^{15} \mathrm{~N}$ abundance. Aus J Plant Physiol 13:699-756

Thuiller W, Richardson DM, Pysek P, Midgley G, Hughes GO, Rouget M (2005) Niche-based modelling as a tool for predicting the risk of alien plant invasions at a global scale. Glob Change Biol 11:2234-2250

Vance CP (2001) Symbiotic nitrogen fixation and phosphorus acquisition. Plant nutrition in a world of declining renewable resources. Plant Physiol 127:390-397

Vance CP, Graham PH, Allan DL (2000) Biological nitrogen fixation: phosphorus a critical future need? In: Pederosa FO, Hungria M, Yates MG, Newton WE (eds) Nitrogen fixation from molecules to crop productivity. Kluwer Academic Publishers, Dordrecht.

Vitousek PM (1990) Biological invasions and ecosystem processes; towards an integration of population biology and ecosystem studies. Oikos 57:7-13

Vosse S (2007) The restoration potential of fynbos riparian seed banks after alien clearing. Master of Science Thesis, Department of Conservation Ecology and Entomology. Stellenbosch University.

Wilson J R, Gaertner M, Griffiths C L, Kotzé I, Le DC, Maitre SMM, Marr SM, Picker M, Spear D, Stafford L, Richardson DM, Van Wilgen BW, Wannenburgh A (2014) Biological invasions in the Cape Floristic Region: history, current patterns, impacts, and management challenges. Fynbos: Ecology, Evolution, and Conservation of a Megadiverse Region (Allsopp, N., Collville, J.F., Verboom, G.A., eds.), pp 273.

Witkowski ETF (1991) Effects of invasive alien Acacias on nutrient cycling in the coastal lowlands of the Cape fynbos. J Appl Ecol 28:1-15

Wolfe LM (2002) Why alien invaders succeed: support for the escape-from-enemy hypothesis. Am Nat 160:705-711

Yelenik SG, Stock WD, Richardson DM (2004) Ecosystem level impacts of invasive Acacia saligna in the South African fynbos. Restor Ecol 12:44-51

Publisher's Note Springer Nature remains neutral with regard to jurisdictional claims in published maps and institutional affiliations. 